\title{
Protection issues in selected European historic towns and their contemporary development
}

\author{
Dominika Kuśnierz-Krupa ${ }^{1, *}$ \\ ${ }^{1}$ Cracow University of Technology, Faculty of Architecture, Podchorążych Street 1, Cracow, Poland
}

\begin{abstract}
The presented article is aimed at presenting a few selected examples of small European historic towns whose properly protected cultural heritage considerably contributes to their development in the $21^{\text {st }}$ century. The issue of protection and revalorisation of Polish towns, particularly the smaller ones, is relevant nowadays. Historic heritage seems to be a burden for local authorities and residents because very often they are not aware of how it could contribute to the multidirectional development of their towns. The local inhabitants and authorities of small historic towns in Western European countries respect their heritage much more than Poles, as they associate it with the idea of sustainable development, "place specificity", and finally, with an opportunity for development, treating cultural heritage as a basis for economic progress and building new and modern infrastructure. It is worth drawing attention here, that sustainable development denotes changing the reality in such a way that the development would optimally satisfy the needs of modern man, without violating the needs of future generations. The testimony to the potential of the cultural heritage of historic towns in the context of their modern development is borne by the towns whose authorities and inhabitants were able to utilise their past for building their future. As examples one could name here French (e.g. Auxerre, Provins,) or German towns (e.g. Heppenheim, Lorsch).
\end{abstract}

\section{Introduction}

Cultural heritage constitutes an important factor in the life of every community, and consequently, also in the process of its further development. The United Nations Educational, Scientific and Cultural Organization, being an organisation trying, e.g. to ensure that next generations could use the heritage, worked out their own definition of cultural heritage (patrimoine culturel). According to the organisation, the term has a broader scope nowadays, and the activity of UNESCO in this area has been manifested in diverse forms. Currently, cultural heritage is conventionally divided into material heritage that comprises immovable and movable historic objects, and immaterial heritage associated primarily with the tradition of a given community, which is conveyed orally. Cultural heritage is regarded by UNESCO as a vital factor of socio-economic development, a means

${ }^{*}$ Corresponding author: dkusnierz-krupa@pk.edu.pl 
of reaching a compromise in regions suffering from ethnic or religious conflicts, and as a means of expressing the cultural diversity of countries and regions of the world [1].

It should be noted, that during the last several decades, numerous documents were prepared and approved, which has led to strengthening protection and popularising the cultural heritage both on a national level and within international cooperation. These documents include, e.g. the Convention on the protection of the world's cultural and natural heritage from 1972; the Declaration of responsibility towards future generations from 1997; the Convention on the protection of non-material cultural heritage from 2003 and, particularly significant in the context of this article, the UNESCO recommendation concerning the historic urban landscape from 2011 [2].

The above mentioned document includes, e.g. several observations concerning the current situation relating to the protection of the cultural heritage of towns and, generally speaking, urbanised areas. It draws attention to the fact that "historic urban areas are among the richest and most diversified manifestations of our shared cultural heritage, which were shaped by subsequent generations and bear testimony to the activity and aspirations of man in time and space". According to UNESCO, urban heritage is for mankind its social, cultural and economic capital created as a result of the historic accumulation of values resulting from the old and contemporary cultures, as well as accumulated traditions and experience. The organisation has also observed that, nowadays, urbanisation develops on an unprecedented scale in the history of mankind, which results in socio-economic changes. Unfortunately, this development is frequently uncontrollable and has a negative impact on urban areas and their surroundings, which can cause the degradation of urban heritage. Therefore, more emphasis should be placed on preparing strategies concerning the preservation and management of historic towns, as well as on planning their development in a more coordinated way, from local initiatives to international undertakings [3].

Problems with protecting historic towns, as well as successful management of their cultural heritage in the context of their development, seem to be particularly relevant nowadays. Protecting cultural heritage in large European cities, including those in Poland, in most cases is properly managed and meticulously monitored by the appropriate services. These cities are generally able to make use of their historic potential for multi-directional development. However, the situation looks quite different in the case of small historic Polish towns. Here, authorities and inhabitants are often incapable of using the opportunity offered by their heritage, as they do not understand its value and the potential it possesses. A good example for Polish historic towns can be set by the historic towns in Western European countries, whose authorities and residents seem to better understand and perceive the value and the opportunities offered by their heritage, treating their cultural heritage as a basis for economic development and building new and modern infrastructure.

\section{The cultural heritage of selected towns and their protection}

The first of the historic towns which is properly preserved and revalorised, and its cultural potential has a significant place in its contemporary development, is Auxerre located in Burgundy, in France. It was founded during the early medieval period, on a hill at the foot of which flows the Yonne River. Almost since its beginning, the town developed quickly which was related to its convenient location at the crossing of land and river routes. It is known, that already in the 3rd century a Gallo-Roman fortress - castrum was erected on the hill. In the following centuries, settlements developed around it which, at the turn of the 11 th and 12th century, were included inside a new line of defensive walls built around the town. Therefore, the urbanised area, namely the medieval town, consisted of the former settlements and the castrum located on the hill. At that time, wine cultivation and farming, floating timber to Paris, as well as trade were sources of income for the town. The 
prosperity of Auxerre was interrupted by the Hundred Years' War which occurred in the years 1337 - 1453 and the Wars of Religion. They caused enormous destruction to the town structure and its architecture. More damage to the town was caused by the Huguenots who seized Auxerre in the year 1567. They desecrated the majority of buildings connected to the Catholic faith [4].

In the 18th century, numerous modernisations and redevelopments were carried out in the town; e.g. medieval ramparts were demolished, the moat was filled in, and in its place new pedestrian walkways were outlined. The 19th century brought more changes to the structure of Auxerre. It was then that the town expanded its infrastructure by erecting, e.g. the railways station, the hospital, the prison and courthouses. Also at that time, building development on the right bank of the river began to crystallise. The 20th century, in turn, resulted in the appearance of e.g. a covered market hall (no longer existing), and art-deco architecture whose numerous examples have survived until today in the town centre.

It is worth mentioning that Auxerre did not suffer much damage during World War II, as a result of which the cultural heritage of the town has survived in good condition until the present. It is significant that since 1976 the town has had a conservation protection zone encompassing an area of 67 ha, and in 1995 it was awarded the title of "Town of Art and History". The title is associated with the policy of protecting and promoting the French heritage, which commenced in the year 1985 by the French Ministry of Culture and Communications. To the towns and regions, particularly valuable from the cultural viewpoint, the Ministry has granted the title of 'Ville ou Pays d'art et d'histoire,' thanks to which the Ministry ensures financial and technological support to enterprises relating to heritage protection and revalorization in their area [5].

Besides the early-medieval urban layout, the cultural landscape of Auxerre also consists of the cathedral of St. Etienne, the abbey of St. Germain and many historic buildings and tenement houses.
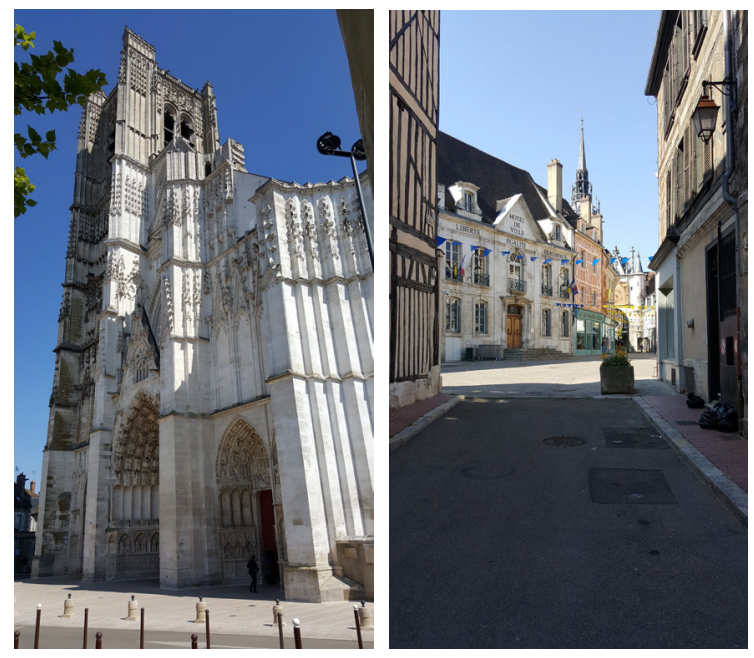

Fig. 1. View of the medieval cathedral in Auxerre nowadays. Photo: D. Kuśnierz-Krupa.

Fig. 2. View of historic buildings in the town nowadays. Photo: D. Kuśnierz-Krupa.

The second among the described historic towns is Provins, located to the south-west of Paris. The town was founded during the early medieval period. Its existence was first mentioned at the beginning of the 9th century. Its location at the crossing of important trade routes at the time, as well as the policy of Counts of Champagne wanting to increase the significance of the province in France, influenced the development of the town, primarily as 
a trade centre. Provins then consisted of two parts: the upper and the lower town. The upper town, located on the hill, was the town of rulers. Here stood the castle of the Counts of Champagne, the Saint-Quiriace collegiate church, the houses of knights, clergymen and lay officials and stretched along the small, rectangular market square. The lower town was situated at the foot of the upper town. Trade was conducted here; merchants, craftsmen and other residents of Provins also lived here. The district formed around the Saint Ayoul abbey near which, already in the 11 th century, fairs were held to commemorate its patron saint. The fairs, originally associated with religious holidays, grew bigger with time, and the town became famous for them as they attracted crowds of merchants [6].

At the turn of the 12th and 13th, century Provins was one of the most important towns in Champagne. The paramount importance of Provins, as well as of other towns in Champagne, declined in the 14th century when Paris became the centre of commercial exchange in this part of France. Such a state of affairs had a huge impact on the present-day cultural heritage of the town. As a result of stagnation and impoverishment of Provins, in the following centuries people used the largely medieval buildings, thus avoiding constructing new houses. A similar situation occurred in the case of public utility buildings; therefore we can still admire unique examples of original, medieval architecture today [6].

Nowadays Provins is under the highest-level of protection, since its historic heritage of extreme cultural value was acknowledged in 2001, by inscribing the town into the UNESCO World Heritage List. For the town's authorities the distinction is not only something to be proud of, but also an obligation to properly maintain the historic heritage, constantly revalorise it, and to educate the community about protecting the town's heritage [8].

The historic heritage of the town, which is under protection, currently consists primarily of relics of defensive ramparts with 22 towers, Cesar tower, relics of medieval housing, churches, especially the collegiate church of Saint Quiriace, and the urban layout. It can be said that nowadays Provins is a kind of open-air museum of medieval urban design and architecture. Interestingly, in this "open-air museum" the majority of historic objects remain in the hands of private owners whose attempts at preservation and revalorisation are supported by the town's authorities e.g. in the form of subsidies.
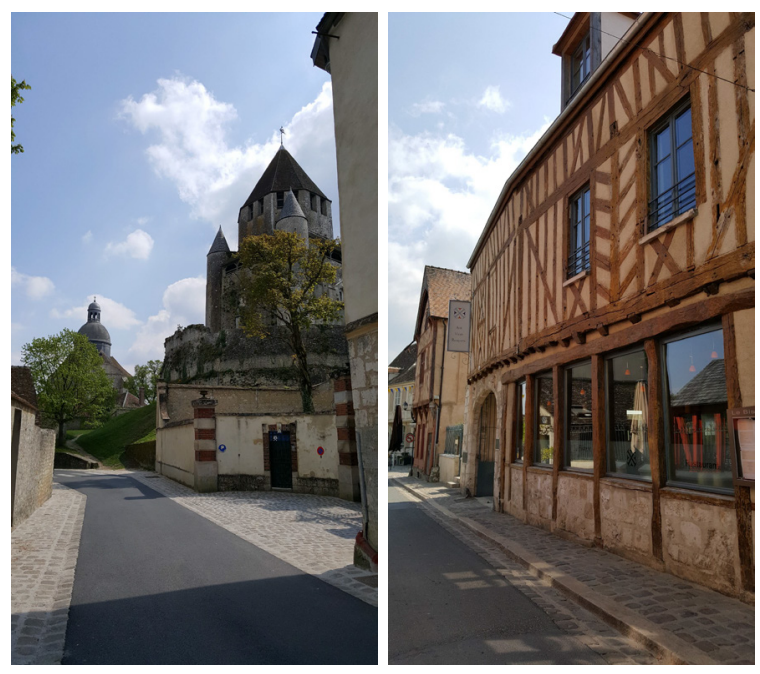

Fig. 3. View of the medieval Cesar tower with the Saint Quiriace church in the background, nowadays. Photo: D. Kuśnierz-Krupa.

Fig. 4. View of the historic buildings in Provins nowadays. Photo: D. Kuśnierz-Krupa. 
Another interesting example of a historic town that uses its cultural potential for contemporary development is Heppenheim, located in Hessen, in western Germany.

Heppenheim was granted its town rights at the beginning of the 14th century, but it had been founded much earlier. The oldest sources mentioning the town date back to the 8th century. Slightly later Heppenheim, by the order of Charlemagne, became a part of the endowment of the Lorsch abbey and for centuries to come remained under the rule of the abbey [9].

Heppenheim never grew into a large city. Until the 19th century it had remained a small town with framework buildings characteristic for Germany. Residents of Heppenheim earned their living as craftsmen organised into merchants' associations - guilds, farmers and wine growers [10].

The industrialisation process, developing in Europe in the 19th century, reached Heppenheim gradually, thanks to which the town preserved its craftsmanship-agricultural character. In the year 1846, the railway line Main - Neckar was built in the town, as a result of which new public utility objects were erected in the town, communal infrastructure improved, the number of inhabitants and the town area increased.

The development of the town commenced in the 19th century and was interrupted by the outbreak of World War I, and then World War II [11]. In the years of the crisis during the Weimar Republic, Heppenheim developed very slowly. The town also experienced the gloomy period of Nazi dictatorship during World War II in which the Jewish residents of the town did not survive.

From the town's heyday its rich cultural heritage has been preserved until today, which comprises e.g. the medieval, pentagonal market square with restored 17 th-century timber framework houses, the Baroque town hall, the parish church dedicated to St. Peter, the 13th-century Starkenburg castle, the courthouse of the Mainz Electorate from the 14th century, and a multitude of the 16th, 17th and 18th century houses characteristic for smalltown German architecture [12].

That valuable heritage has been properly protected by the town's authorities, inhabitants, as well as suitable legal regulations but, primarily it is well-advertised and used to develop the town. For instance, it was used as a basis for developing cultural tourism and numerous attractions associated with the history and tradition of the town.
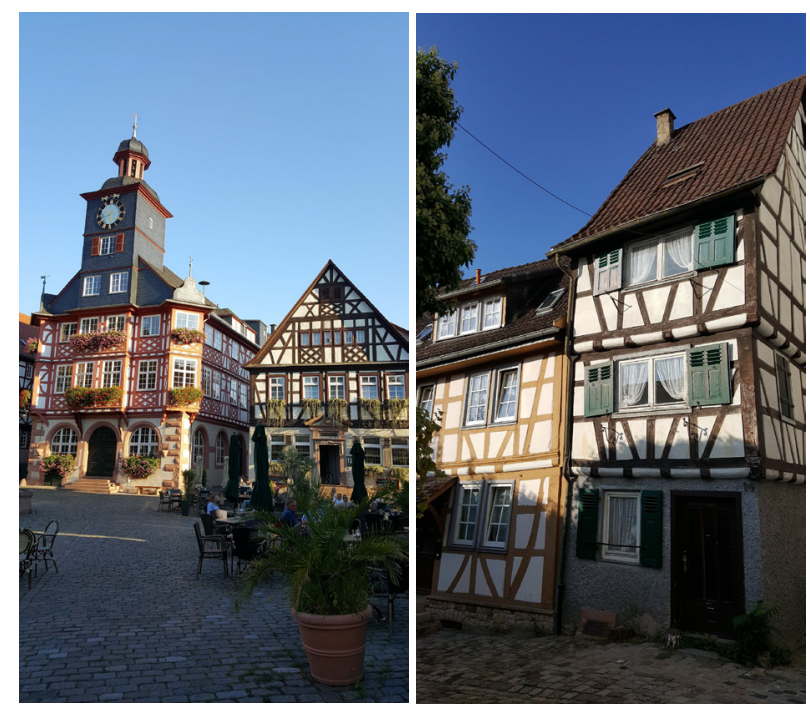

Fig. 5. View of the historic town hall in Heppenheim nowadays. Photo: D. Kuśnierz-Krupa.

Fig. 6. View of the historic, timber frame buildings in the town nowadays. Photo: D. Kuśnierz-Krupa. 
The last of the presented urban centres is Lorsch, a small town located in the valley of the Rhine, in the lower reaches of the Weschnitz River, to the west of Odenwald, between Darmstadt in the north and Mannheim in the south.

The history of Lorsch is inextricably connected to the history of Altenmünster, as well as the other monastic complex located in its vicinity. Altenmünster was founded by the Franconian count Concor and his mother Williswinda in the 2 nd half of the 8 th century. The original complex comprised the church which was to be the necropolis of its founders, and monastery buildings, most probably wooden. The first abbot of Lorsch, Chrodegang, obtained from Pope Paul I the body of St. Nazarius, a martyr from the times of Diocletian, whose grave in Lorsch was to be visited by crowds of pilgrims. That must have been the reason for building a new church and an abbey, which were erected on the nearby sand dune from the glacial period, to the west of Altenmünster [13].

A personage of vital importance for the development of Lorsch was Charlemagne himself, and his descendants, who visited the abbey many times. It was thanks to their privileges and endowments, among other things, that Lorsch soon became not only very wealthy but also influential, coming directly and solely under the emperor's authority.

The turn of the 11th and 12th century brought new privileges and endowments for the monastery in Lorsch. They were granted by subsequent rulers who frequently visited the abbey. Although by the power of previous privileges and endowments, the monastery enjoyed sovereign territorial rights, it was repeatedly entangled in local conflicts, which undermined its position. The last representative of the Benedictine Order ruled the abbey in Lorsch until 1226. It was then that the period of the monastery's independence finished. The care of the complex was taken over by the archbishop of Mainz, Siegfried III. About a decade later Cistercians moved into the Lorsch abbey, and in the year 1248 - Norbertines [14].

The abbey was dissolved in the mid-16th century. It was a result of the introduction of the Reformation in the fiefs of the Elector Palatine, to which Lorsch then belonged.

The fate of the abbey was sealed during the $1620 \mathrm{~s}$, when both the monastery buildings and the town itself were badly damaged as a result of the Thirty Years' War. Although the archbishopric of Mainz regained their influence in Lorsch and the Catholic faith was restored, the abbey never regained its former position. The remains of ruined monastic objects served as building materials and were never reconstructed. Thus ended the era of dominance of the Lorsch Abbey that, powerful, wealthy and influential during the early and high medieval period, finally ceased to exist in the 17 th century.

Despite the collapse of the abbey, from its most glorious period and the later centuries, several relics of its magnificent architecture and other elements of the cultural landscape of the town have survived until our times. They are: relics of Altenmünster, relics of the other monastic complex regarded as one of the most famous Carolingian complexes [15] including, e.g. the preserved fragment of the basilica of St. Nazarius, the south-east section of the monastery wall and the famous "Torhalle" with the King's Hall, as well as the medieval town with historic framework buildings.

In the year 1991 the abbey and Altenmünster monastery from Lorsch were inscribed in the UNESCO World Heritage List [16]. So far, the town is the only one in Hessen, whose cultural heritage has been so distinguished. Since that time, revalorisation work has been carried out in the former abbey as well as the town, which is meant to protect that valuable heritage and make more historic places accessible to visitors. Extending the tourist offer by e.g. creating tourist routes associated with e.g. relics of monastic complexes, medieval tradition of herbalism, organising educational workshops, festivals, holiday fairs and a heritage protection day, are examples of skilfully using the cultural heritage for contemporary development of that small town. 


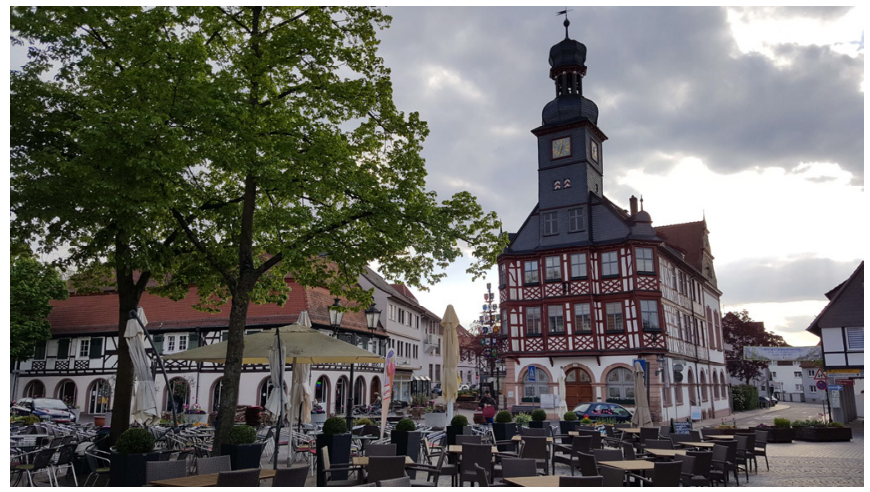

Fig. 7. View of the historic town hall in Lorsch nowadays. Photo: D. Kuśnierz-Krupa.

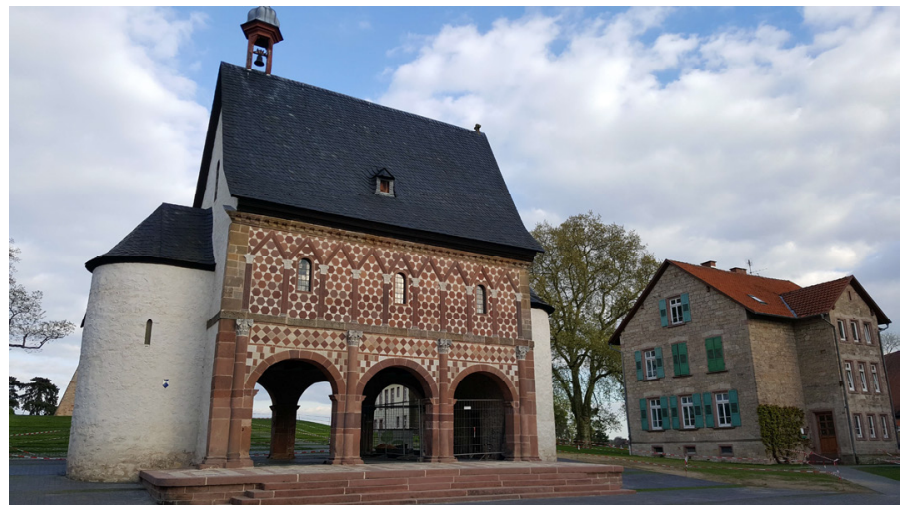

Fig. 8. View of the revalorised "Torhalle" nowadays. Photo: D. Kuśnierz-Krupa.

\section{Summary}

In the conclusion to this article attention should be drawn to the fact that the abovementioned examples of historic towns from Western Europe are characterised by well-preserved and properly protected cultural heritage. In the case of Provins and Lorsch, this protection is maintained at a very high level due to the fact that both these centres were inscribed in the UNESCO World Heritage List. In the case of protecting the historic value of Auxerre, one should emphasise the importance of the town being awarded the title Ville ou Pays d'art et d'histoire, and thus being included among the most culturally valuable towns in France. The title obliges the local authorities to control the current state of preservation of the cultural heritage and its restoration. In turn, the protection of the cultural heritage of Heppenheim is based on the national programme of monument protection, which seems sufficient considering its state. Now, one should address the issue of the place of cultural heritage in the process of developing a historic town. There is no future without the past; therefore, in the author's opinion, the role of historic heritage cannot be ignored while planning activities aimed at the multi-directional development of a town. Even more so, when the heritage is as unique and valuable as in the case of the urban centres analysed above. It is the duty of the town's authorities and, indirectly, its inhabitants to skilfully manage that heritage in order to ensure a better future, and better living conditions for future generations. Finally, addressing the issues of the preservation of historic towns in Poland, one has to say generally that current conservation protection of such urban centres 
is insufficient in many cases. Neither their authorities nor their inhabitants seem to understand the need to protect that heritage and, consequently, do not perceive it as an asset in the development of their towns. Therefore, quoting examples from abroad, where implementing several positive activities associated with the restoration, popularisation and promotion of heritage is noticeable, seems to be vital and relevant. In this aspect, small towns from Western Europe might set positive examples for Polish towns for implementing procedures for protecting their cultural landscape in connection with its use for their development.

\section{References}

1. http://www.unesco.pl/kultura/dziedzictwo-kulturowe/, access: 10.04.2018

2. http://www.unesco.pl/instrumentarium-prawne/, access: 11.04 .2018

3. http://www.unesco.pl/fileadmin/user_upload/pdf/Rekomendacje/Zalecenie_w_sprawie _krajobrazu_miejskiego.pdf, access: 11.04 .2018

4. Pays de Bourgogne. Auxerre, F. Nedellec (edit.), 3-45, (no 229, 2011)

5. http://www.vpah.culture.fr/, access: 11.04.2018

6. Provins. World Heritage, A. Metternich (edit.), 10-50, (Connaissance des Arts, 2006)

7. M. Veissiere, Histoire de Provins et sa région, 5-50, (Toulouse, Editions Privat, 1988)

8. https://whc.unesco.org/en/list/873/documents/, access: 05.04.2018

9. F. Muller, Heppenheim Erleben, 10-13, ( Edition Diesbach, 2007)

10. W. Metzendorf, Heppenheimer Lexikon - Ein ortskundliches Geschichtsbuch: Flurnamen, Gebäude, Strassen und Plätze (Laurissa 1994)

11. 1200 Jahre Heppenheim. Im Gedenken an die erste urkundliche Erwahnung Heppenheims am 17. Juli 755, Herausgegeben vom Magistrat der Kreisstadt Heppenheirn an der Bergsrafśe (1955)

12. D. Kuśnierz-Krupa, M. Krupa, Heppenheim - a model example of well - used cultural potential of a small town, 161-180, (JCEE no 3/II/17)

13. D. Kuśnierz-Krupa, M. Krupa, Lorsch - Carolingian heritage. Introduction to research on the cultural heritage of the town, 20-30, (Journal of Heritage Conservation no 50/2017)

14. Geschichtsblätter für den Kreis Bergstraße. Beiträge zur Geschichte des Klosters Lorsch (Lorsch, 1980)

15. X. Barral I Altet, The Early Middle Ages: From Late Antiquity to A.D. 1000, 150, (Taschen, 1998)

16. http://whc.unesco.org/en/list/515, access: 10.04.2018 